\title{
THE EXECUTION OF THE FEDERAL BUDGET FOR JANUARY-OCTOBER 2016: SHRINKAGE OF THE OIL AND GAS DEFICIT ${ }^{1}$
}

\author{
A. Mamedov, E. Fomina
}

As demonstrated by reported monthly performance data, the RFfederal budget for the first 10 months of 2016 was executed with a deficit of $-2.3 \%$ of GDP (vs. $-1.0 \%$ of GDP over the same period of 2015). By the year-end of $2016^{2}$, the plunge of total federal budget revenue is not expected to exceed 0.8 p.p. of GDP (as compared with 2015), this result to be secured by an increased nonoil and gas revenue component. The year-end movement pattern of expenditure in 2016 is going to be exactly reverse: its amount is expected to increase by 0.5 p.p. of GDP, due in the main to the additional allocation, in November, of $R b$ 739.7bn to national defense.

\section{Revenue and Expenditure: General Estimates}

In accordance with the RF Federal Treasury's monthly performance reports, RF federal budget revenue as of 1 November 2016 amounted to $15.4 \%$ of GDP (or Rb $10,440.6 \mathrm{bn}$ ), which is 1.9 p.p. of GDP below the corresponding figure for the same period of 2015 (a drop by nearly $8 \%$ in nominal terms - see Table 1). The plunge of aggregate federal budget revenue in January-October 2016 was caused by the radical shrinkage of its oil and gas component. Over the first 10 months of 2016, the amount of oil and gas revenues shrank in nominal terms on the corresponding period of last year by $22.5 \%$, or by nearly 2 p.p. of GDP.

At the same time, the amount of non-oil and gas revenues in terms of share of GDP remained at the previous level, while increasing in nominal terms by $3.5 \%$. For 2016, the RF Ministry of Finance expects the year-end total federal budget revenue to decline by only 0.8 p.p. of GDP (as compared with 2015), which will be made possible by the non-oil and gas component's growth (by 0.8 p.p. of GDP).

The improved dynamics of the non-oil and gas revenues in the federal budget over recent months has had to do with the expected proceeds to be generated by the partial privatization of PAO Rosneft ${ }^{3}$. However, it is still doubtful if this deal can actually be closed before the year-end of 2016.

Federal budget expenditure executed over January-October 2016 amounted to $17.7 \%$ of GDP, which is 0.6 p.p. of GDP below the corresponding index for the first 10 months of 2015. The expenditure volume in nominal terms

1 This paper was originally published in Monitoring of Russia's Economic Outlook No.19(37). 2 Hereinafter, the estimates for the year-end execution of the RF federal budget are based on the Explanatory Note for the Draft Federal Law 'On the Federal Budget for 2017 and Planning Period 2018 and 2019'.

3 These revenues are not charged to the sources for covering budget deficit; instead, they are entered on the revenue side due to the multi-tiered public ownership structure of PAO Rosneft (through OJSC Rosneftegaz; once the transaction is completed, all the revenues generated by it must be transferred to the federal budget as early as 2016, to offset the dividends payable on shares in 2017 and the year-end dividends for 2016). 
MAIN PARAMETERS OF THE FEDERAL BUDGET FOR JANUARY-OCTOBER 2015-2016

\begin{tabular}{|c|c|c|c|c|c|c|c|c|}
\hline & \multicolumn{2}{|c|}{2015} & \multicolumn{2}{|c|}{2016} & \multicolumn{2}{|c|}{$\begin{array}{l}\text { Change over first } \\
10 \text { months of } 2016 \\
\text { relative to first } 10 \\
\text { months of } 2015\end{array}$} & \multicolumn{2}{|c|}{$\begin{array}{c}\text { Implementation } \\
\text { of annual } \\
\text { targets }\end{array}$} \\
\hline & $\begin{array}{c}10 \\
\text { months } \\
\text { (actual) }\end{array}$ & $\begin{array}{c}\text { Year } \\
\text { (actual) }\end{array}$ & $\begin{array}{c}10 \\
\text { months } \\
\text { (actual) }\end{array}$ & $\begin{array}{l}\text { Year (esti- } \\
\text { mated) }\end{array}$ & \multirow{2}{*}{$\begin{array}{l}\text { p.p. } \\
\text { of } \\
\text { GDP }\end{array}$} & \multirow[t]{2}{*}{$\begin{array}{c}\text { nominal growth } \\
\text { rate, } \%\end{array}$} & $\begin{array}{c}10 \\
\text { months } \\
\text { of } 2015\end{array}$ & $\begin{array}{c}10 \\
\text { months } \\
\text { of } 2016\end{array}$ \\
\hline & \multicolumn{4}{|c|}{$\%$ of GDP } & & & \multicolumn{2}{|c|}{$\%$} \\
\hline Revenue, including: & 17.3 & 16.9 & 15.4 & 16.1 & -1.9 & -7.9 & 83 & 78 \\
\hline oil and gas revenues & 7.6 & 7.3 & 5.7 & 5.8 & -1.9 & -22.5 & 85 & 81 \\
\hline $\begin{array}{l}\text { non-oil and gas } \\
\text { revenues }\end{array}$ & 9.7 & 9.6 & 9.7 & 10.4 & 0.0 & +3.5 & 82 & 77 \\
\hline $\begin{array}{l}\text { Expenditure, } \\
\text { including: }\end{array}$ & 18.3 & 19.3 & 17.7 & 19.8 & -0.6 & +0.3 & 77 & 73 \\
\hline interest & 0.7 & 0.6 & 0.8 & 0.8 & +0.2 & +27.4 & 83 & 86 \\
\hline non-interest & 17.6 & 18.7 & 16.9 & 19.0 & -0.7 & -0.7 & 77 & 73 \\
\hline $\begin{array}{l}\text { Federal budget } \\
\text { surplus (deficit) }\end{array}$ & -1.0 & -2.4 & -2.3 & -3.7 & +1.3 & +144.6 & 33 & 52 \\
\hline non-oil and gas deficit & -8.6 & -9.7 & -8.0 & -9.4 & -0.6 & -3.3 & 72 & 70 \\
\hline $\begin{array}{l}\text { For reference: GDP } \\
\text { at current prices }\end{array}$ & 65,612 & 80,804 & 67,775 & 82,815 & - & +3.3 & - & - \\
\hline
\end{tabular}

Source: for 2015 and the first 10 months of 2016 - the RF Federal Treasury's reports; for 2016 - preliminary estimates released by the RF Ministry of Finance; own calculations.

increased by $0.3 \%$, largely due to the significant rise in the amount of budgeted interest on public debt in the federal budget (by $27.4 \%$ ).

The growth of expenditures related to public debt servicing resulted from the increased domestic debt servicing costs (by 43\%) coupled with the slightly reduced foreign debt servicing costs (by $2 \%$ ). One of the relevant factors was the accelerated debt growth rate in 2016: while over the entire year-long period of 2015 Russia's domestic debt had gained less than $1.8 \%$, over the first 10 months of 2016 alone that index jumped by $6 \%$.

The year-end result of 2016 is expected to demonstrate growth of total budget expenditure not only in nominal terms, but also in terms of share of GDP (by 0.5 p.p.), first of all due to the allocation of an additional $\mathrm{Rb} 739.7 \mathrm{bn}$ to national defense (mainly earmarked for the redemption of debts owed by defense enterprises against their loans). In the end, the execution of federal budget expenditure over the first 10 months of 2016 (as a percentage of the annual expenditure ceiling) turned out to be 4 p.p. below the corresponding index for the same period of 2015 , thus pointing to the increasingly uneven expenditure distribution. For the last two months of the year 2016, there remains $27 \%$ of the annual expenditure target.

As shown by the period-end results for January-October 2016, the RF federal budget was executed with a deficit of $2.3 \%$ of GDP, which is 1.3 p.p. of GDP above the amount of deficit for the corresponding period of 2015. According to the RF Ministry of Finance's preliminary year-end estimates, the annual federal budget deficit growth in 2016 will not exceed 1.3 p.p. of GDP relative to its 2015 index. Meanwhile, the non-oil and gas deficit in 2016 is going to decline, both based on the period-end result of the first 10 months and in per annum terms. 
TAX RECEIPTS IN THE FEDERAL BUDGET OVER JANUARY-OCTOBER 2015-2016

\begin{tabular}{|c|c|c|c|c|c|c|c|c|}
\hline & \multicolumn{2}{|c|}{2015} & \multicolumn{2}{|c|}{2016} & \multicolumn{2}{|c|}{$\begin{array}{l}\text { Change over first } \\
10 \text { months of } 2016 \\
\text { relative to first } 10 \\
\text { months of } 2015\end{array}$} & \multicolumn{2}{|c|}{$\begin{array}{c}\text { Implementation } \\
\text { of annual } \\
\text { targets }\end{array}$} \\
\hline & $\begin{array}{c}10 \\
\text { months } \\
\text { (actual) }\end{array}$ & $\begin{array}{c}\text { Year } \\
\text { (actual) }\end{array}$ & $\begin{array}{c}10 \\
\text { months } \\
\text { (actual) }\end{array}$ & $\begin{array}{l}\text { Year (esti- } \\
\text { mated) }\end{array}$ & \multirow[t]{2}{*}{$\begin{array}{l}\text { p.p. of } \\
\text { GDP }\end{array}$} & \multirow[t]{2}{*}{$\begin{array}{c}\text { nominal } \\
\text { growth rate, \% }\end{array}$} & $\begin{array}{c}10 \\
\text { months } \\
\text { of } 2015\end{array}$ & $\begin{array}{c}10 \\
\text { months } \\
\text { of } 2016\end{array}$ \\
\hline & \multicolumn{4}{|c|}{$\%$ of GDP } & & & \multicolumn{2}{|c|}{$\%$} \\
\hline $\begin{array}{l}\text { Tax-generated rev- } \\
\text { enues, total, including }\end{array}$ & 15.3 & 14.7 & 13.7 & 13.5 & -1.5 & -7.1 & 84 & 83 \\
\hline $\begin{array}{l}\text { tax on profit of } \\
\text { organizations }\end{array}$ & 0.7 & 0.6 & 0.6 & 0.6 & 0.0 & -3.5 & 90 & 92 \\
\hline $\begin{array}{l}\text { VAT on goods pro- } \\
\text { duced in RF territory }\end{array}$ & 3.3 & 3.0 & 3.4 & 3.2 & +0.2 & +8.6 & 87 & 88 \\
\hline $\begin{array}{l}\text { VAT on goods import- } \\
\text { ed into RF territory }\end{array}$ & 2.2 & 2.2 & 2.3 & 2.3 & +0.1 & +7.9 & 80 & 81 \\
\hline $\begin{array}{l}\text { Excises on goods pro- } \\
\text { duced in RF territory }\end{array}$ & 0.7 & 0.7 & 0.8 & 3.2 & +0.1 & +19.4 & 82 & 83 \\
\hline $\begin{array}{l}\text { Excises on goods } \\
\text { imported into } \\
\text { RF territory }\end{array}$ & 0.1 & 0.1 & 0.1 & 0.1 & 0.0 & +11.7 & 76 & 81 \\
\hline $\begin{array}{l}\text { Tax on mineral } \\
\text { resources extraction }\end{array}$ & 4.1 & 3.9 & 3.4 & 3.4 & -0.7 & -14.1 & 85 & 81 \\
\hline $\begin{array}{l}\text { Revenues gener- } \\
\text { ated by foreign trade } \\
\text { (customs duties) }\end{array}$ & 4.2 & 4.1 & 3.0 & 3.1 & -1.1 & -24.8 & 83 & 80 \\
\hline
\end{tabular}

Source: for 2015 and the first 10 months of 2016 - the RF Federal Treasury's reports; for 2016 - preliminary estimates released by the RF Ministry of Finance; own calculations.

So, the federal budget is becoming de facto less dependent on the situation in the world energy carriers markets, but this is hap.p.ening not because of an increasing diversification of the Russian economy, but due to the significant shrinkage of the volume (and thus the budget share) of oil and gas revenues.

\section{Tax-generated Revenues}

The parameters of the execution of the federal budget on its revenue side over the first 10 months of 2016 are presented in Table 2 . When analyzing the movement of the actual amount of tax receipts over that period, we noted their plunge by 1.5 p.p. of GDP as compared with the same period of 2015.

The shrinkage of tax receipts was caused in the main by the corresponding plunge of oil and gas revenues not only in terms of share of GDP, but also in absolute terms. The receipts of customs duties shrank by $25 \%$ in nominal terms, of by 1.1 p.p. of GDP (largely due to the reduced export duties on oil and petroleum products). The loss of tax on mineral resources extraction in nominal terms was as high as $14 \%$, or 0.7 p.p. of GDP. Overall, the shrinkage of oil and gas revenues was caused by the significant plunge in oil prices ${ }^{1}$. However, these budget changes were partly offset by the ruble's weakening relative to the US dollar².

1 Over the first 10 months of 2016 , the average price of Urals was $\$ 40.7$ per barrel vs. $\$ 53.6$ per barrel over the corresponding period of 2015.

2 The average ruble-to-USD exchange rate over the first 10 months of 2016 was Rb $67.7 \mathrm{vs.}$ $\mathrm{Rb} 59.4$ over the corresponding period of 2015. 
It can also be noted that in 2016 , the ceiling for the rate of export duty on oil was left at the level of $42 \%$, while that of tax on mineral resources extraction for oil was raised from $\mathrm{Rb} 766$ to $\mathrm{Rb} 857$ per tonne. These legislative innovations, which actually went contrary to the logic of the ongoing tax maneuver, also helped prevent some of the potential federal budget loss that could result from the plummeting oil prices.

At the same time, the receipts of some other taxes increased both in nominal terms and in terms of share of GDP. Thus, the federal budget receipts of VAT on goods produced in RF territory gained $8.6 \%$ in nominal terms, or 0.2 p.p. of GDP; the revenues generated by VAT on imports increased by $7.9 \%$ in nominal terms, or by 0.1 p.p. of GDP; and the excises on goods produced in RF territory - by $19.4 \%$ or 0.1 p.p. of GDP respectively. The higher revenue inflow generated by these taxes could only in part compensate for the lost oil and gas revenues, and $\mathrm{sp}$ it failed to reverse the overall downward trend displayed by the volume of tax receipts.

\section{The Reliability of Planned Targets}

The significant deviation of the actual budget execution over the first 10 months of 2016 from its execution indices for the same period of 2015 may be indicative of the fact that the planned annual revenue targets for 2016 were insufficiently substantiated. If we compare the data in the last two columns in Table 2, no significant differences between 2015 and 2016 will be seen. At the same time, the level of budget execution over the first 10 months of 2016 for the majority of taxes pertaining to non-oil and gas revenues was somewhat higher than a year earlier. All other conditions being equal, this may point to the annual receipts targets set for these taxes being conservative (because if the budget execution indices for the first 10 months of 2016 remain at the same level as in 2015, the year-end result of 2016 can be expected to be above the target planned by the RF Ministry of Finance).

From this point of view, the greatest deviation from the planned target was displayed by the excises on goods imported into RF territory (5 p.p.). A reverse situation can be observed with regard to tax on mineral resources extraction and customs duties (revenues generated by foreign trade): our analysis of the actual receipts demonstrates that the annual targets set for 2016 were somewhat overestimated. However, bearing in mind that the key indicator in this case is the price of oil, which in H2 2016 moved over a higher trajectory than in $\mathrm{H} 1$, the estimates for the receipts of tax on mineral resources extraction and customs duties released by the RF Ministry of Finance appear to be quite realistic (due to the favorable trend displayed by prices of oil, the share of receipts over the last 2 month may well become higher than the corresponding index for last year).

Table 3 demonstrates the by-function distribution of federal budget expenditure over the period 2015-2016 (10-month-period-end and year-end data). If we compare the movement of various budget functions as shown in Table 3, it will become obvious that the plunge in the total federal expenditure volume over the period of January-October 2016 was caused in the main by the shrinkage of allocations to national defense by 0.5 p.p. of GDP as a result of their slower implementation relative to the same period of 2015 ( $56 \%$ vs. $76 \%$ respectively). The upshot is that nearly $50 \%$ of the actually allocated expenditure will have to implemented during the year's last 2 months. However, it must be remembered that such a situation emerged primarily 
FEDERAL BUDGET EXPENDITURE OVER JANUARY-OCTOBER 2015-2016

\begin{tabular}{|c|c|c|c|c|c|c|c|c|}
\hline & \multicolumn{2}{|c|}{2015} & \multicolumn{2}{|c|}{2016} & \multicolumn{2}{|c|}{$\begin{array}{l}\text { Change over first } \\
10 \text { months of } 2016 \\
\text { relative to first } 10 \\
\text { months of } 2015\end{array}$} & \multicolumn{2}{|c|}{$\begin{array}{c}\text { Implementation } \\
\text { of annual } \\
\text { targets }\end{array}$} \\
\hline & $\begin{array}{c}10 \\
\text { months } \\
\text { (actual) }\end{array}$ & $\begin{array}{c}\text { Year } \\
\text { (actual) }\end{array}$ & $\begin{array}{c}10 \\
\text { months } \\
\text { (actual) }\end{array}$ & $\begin{array}{l}\text { Year (esti- } \\
\text { mated) }\end{array}$ & \multirow{2}{*}{$\begin{array}{l}\text { p.p. } \\
\text { of } \\
\text { GDP }\end{array}$} & \multirow[t]{2}{*}{$\begin{array}{c}\text { nominal growth } \\
\text { rate, } \%\end{array}$} & $\begin{array}{c}10 \\
\text { months } \\
\text { of } 2015\end{array}$ & $\begin{array}{c}10 \\
\text { months } \\
\text { of } 2016\end{array}$ \\
\hline & \multicolumn{4}{|c|}{$\%$ of GDP } & & & \multicolumn{2}{|c|}{$\%$} \\
\hline $\begin{array}{l}\text { Expenditure, total, } \\
\text { including: }\end{array}$ & 18.3 & 19.3 & 17.7 & 19.8 & -0.6 & +0.3 & 76.7 & 73.3 \\
\hline Nationwide issues & 1.2 & 1.4 & 1.2 & 1.3 & 0.0 & +5.5 & 71.6 & 76.9 \\
\hline National defense & 3.7 & 3.9 & 3.2 & 4.7 & -0.5 & -10.1 & 76.3 & 56.1 \\
\hline $\begin{array}{l}\text { National security and } \\
\text { law-enforcement activity }\end{array}$ & 2.3 & 2.4 & 2.1 & 2.3 & -0.2 & -4.9 & 76.1 & 73.2 \\
\hline National economy & 2.4 & 2.9 & 2.3 & 2.6 & -0.1 & -2.7 & 68.3 & 71.4 \\
\hline $\begin{array}{l}\text { Housing and utili- } \\
\text { ties sector }\end{array}$ & 0.1 & 0.2 & 0.1 & 0.1 & -0.1 & -41.4 & 59.0 & 87.4 \\
\hline Environment protection & 0.1 & 0.1 & 0.1 & 0.1 & 0.0 & +24.5 & 87.0 & 83.4 \\
\hline Education & 0.8 & 0.8 & 0.7 & 0.7 & -0.1 & -4.0 & 85.5 & 89.8 \\
\hline Culture, cinematography & 0.1 & 0.1 & 0.1 & 0.1 & 0.0 & -7.9 & 78.5 & 70.7 \\
\hline Healthcare & 0.6 & 0.6 & 0.6 & 0.6 & 0.0 & +2.0 & 76.3 & 86.1 \\
\hline Social policy & 5.3 & 5.3 & 5.6 & 5.6 & +0.3 & +9.1 & 81.2 & 81.6 \\
\hline $\begin{array}{l}\text { Physical culture } \\
\text { and sports }\end{array}$ & 0.1 & 0.1 & 0.1 & 0.1 & 0.0 & -36.3 & 77.3 & 54.1 \\
\hline Mass media & 0.1 & 0.1 & 0.1 & 0.1 & 0.0 & -22.6 & 88.5 & 74.1 \\
\hline $\begin{array}{l}\text { Government } \\
\text { debt servicing }\end{array}$ & 0.7 & 0.6 & 0.8 & 0.8 & +0.2 & +27.4 & 83.2 & 86.0 \\
\hline Interbudgetary transfers & 0.8 & 0.8 & 0.8 & 0.8 & 0.0 & 0.2 & 78.1 & 81.3 \\
\hline
\end{tabular}

Source: for 2015 and the first 10 months of 2016 - the RF Federal Treasury's reports; for 2016 - preliminary estimates released by the RF Ministry of Finance; own calculations.

due to the fact that an additional sum of $\mathrm{Rb} 739.7 \mathrm{bn}$ was allocated to national defense only after a number of relevant alterations had been made to the current budget law in November 2016 (earmarked in the main for the repayment of loans taken by companies belonging to the defense complex).

A similar trend, albeit on a lower scale, is also typical of the expenditures allocated to national security and law-enforcement activity, which shrank by 0.2 p.p. of GDP over the first 10 months of 2016 alongside a reduction of the degree of their actual implementation from $76 \%$ to $73 \%$. For all the other major budget functions, the expenditure implementation index over the year's first 10 months either remained practically unchanged, or even increased. So, their movement (growth or decline) over January-October 2016 is on the whole compatible with their planned year-end targets.

\section{The Evenness of Budget Execution}

A comparative analysis of the RF Federal Treasury's reports for the first 9 months of 2016 and 2015 from the point of view of by-department distribution of budget expenditure can demonstrate how evenly the budget funds are spent by each ministry and government department. Table 4 shows the list of 10 chief budget funds managers (CBFMs) that achieved the least degree of expenditure implementation (relative to the annual target) over the first 9 months of 2016. In view of the low budget implementation rate demon- 
THE CBFMS WITH THE LEAST DEGREE OF BUDGET EXPENDITURE IMPLEMENTATION OVER THE FIRST 9 MONTHS OF 2016 (RELATIVE TO ANNUAL TARGETS)

\begin{tabular}{|c|c|c|c|c|c|}
\hline \multirow[b]{2}{*}{ No } & \multirow[b]{2}{*}{ CBFMs } & \multirow{2}{*}{$\begin{array}{l}\text { CBFM } \\
\text { code }\end{array}$} & \multicolumn{3}{|c|}{ Budget execution, \% } \\
\hline & & & $\begin{array}{l}9 \text { months } \\
\text { of } 2015\end{array}$ & 2015 & $\begin{array}{l}9 \text { months } \\
\text { of } 2016\end{array}$ \\
\hline 1 & Federal Agency for Ethnic Affairs & 380 & 66.5 & 95.9 & 20.6 \\
\hline 2 & Federal Space Agency & 259 & 39.3 & 91.7 & 21.9 \\
\hline 3 & $\begin{array}{l}\text { RF Ministry of Economic Development } \\
\text { of the Russian Federation }\end{array}$ & 139 & 32.8 & 96.4 & 22.6 \\
\hline 4 & $\begin{array}{l}\text { RF Ministry for the Development } \\
\text { of the Russian Far East }\end{array}$ & 350 & 6.6 & 98.8 & 26.7 \\
\hline 5 & RF Ministry of Communications and Mass Media & 071 & 35.0 & 98.2 & 29.8 \\
\hline 6 & Federal Agency for Air Transport & 107 & 35.2 & 76.3 & 33.5 \\
\hline 7 & Federal Guard Service & 202 & 29.8 & 99.9 & 37.6 \\
\hline 8 & RF Ministry of Sport & 777 & 70.8 & 97.9 & 40.7 \\
\hline 9 & RF Ministry of North Caucasus Affairs & 370 & 13.0 & 99.0 & 41.0 \\
\hline 10 & $\begin{array}{l}\text { Federal Service for Supervision } \\
\text { in Education and Science }\end{array}$ & 077 & 54.1 & 99.4 & 48.1 \\
\hline
\end{tabular}

Source: RF Federal Treasury's reports for 2015-2016; own calculations.

strated by these CBFMs over the financial year's first 9 months, it appears doubtful that budgets funds can be spent with due efficiency in a situation where more than $50 \%$ of the total expenditure allocated to each of these departments is left for the year's last quarter.

It is noteworthy that, for a second year in a row, 8 out of the 10 CBFMs listed in Table 4 have left more than half of the annual sum allocated to them to be spent over the year's last quarter. Another important phenomenon is that, by the year-end of 2015, only 2 out of these 8 agencies implemented significantly less than $100 \%$ of their budget allocations (the Federal Agency for Air Transport and the Federal Space Agency). As a result, the remaining 6 agencies were able to implement $50 \%$ or more of their annual allocations during the year's last quarter. In order to improve budgetary discipline and ensure even spending of budget funds, in 2016 the rule was introduced whereby the CBFMs, after 30 September of each year, were no longer allowed to assume obligations associated with supplies of goods, performance of work, and delivery of services (with the exception of those executed in the framework of government defense orders and some other types of expenditure) ${ }^{1}$.

As follows from our analysis, in 2016 neither the budget execution pattern not budget sustainability demonstrated an improvement, which casts doubt concerning the efficiency of the current measures designed to improve the quality of financial management practiced by the CBFMs.

1 Decree of the RF Government of April 4, 2016, No. 266 'On Introducing Alterations into Decree of the RF Government of the Russian Federation of December 28, 2015, No. 1456 "On Measures Designed to Implement the Federal Law 'On the Federal Budget for 2016'”'. 